\title{
Institutional shelter to protect adolescent victims of domestic violence: theory or practice? ${ }^{1}$
}

\author{
Diene Monique Carlos ${ }^{2}$ \\ Maria das Graças Carvalho Ferriani ${ }^{3}$ \\ Marta Angelica lossi Silva ${ }^{4}$ \\ Eliana Mendes de Souza Teixeira Roque ${ }^{5}$ \\ Telma Sanchez Vendruscolo ${ }^{5}$
}

\begin{abstract}
Objective: To understand and analyze, from the perspective of adolescent victims of domestic violence who were cared for in an institution in Campinas-SP, the protective factors to which they are submitted and / or have access. Method: This was qualitative research, with data collection occurring through focus groups with 17 adolescents, and semistructured interviews with seven of them; the data analysis was based on content analysis, using a thematic modality. Results: Two themes emerged, entitled Four Walls and Trust. We discuss the context of institutional care, that despite the efforts made contemporaneously, still maintains an authoritarian environment; the importance of the bond and trust established with some employees, acting as protective factors for the adolescents and the protective aspect of religiosity. Conclusions: It is understood that these considerations should be valued and reinforced through the healthcare services provided to children and adolescents, as they contribute to the promotion of the physical and mental health of this population.
\end{abstract}

Descriptors: Adolescent; Domestic Violence; Refuge; Protection.

\footnotetext{
${ }^{1}$ Paper extracted from Doctoral Dissertation "Fatores de proteção sob a ótica de adolescentes vítimas de violência doméstica e abrigados - subsídios para a construção da resiliência", presented to Escola de Enfermagem de Ribeirão Preto, Universidade de São Paulo, WHO Collaborating Centre for Nursing Research Development, Ribeirão Preto, SP, Brazil.

${ }^{2}$ Doctoral Student, Escola de Enfermagem de Ribeirão Preto, Universidade de São Paulo, WHO Collaborating Centre for Nursing Research Development, Ribeirão Preto, SP, Brazil. RN, Prefeitura Municipal de Campinas, Campinas, SP, Brazil.

${ }_{3}^{3}$ PhD, Full Professor, Escola de Enfermagem de Ribeirão Preto, Universidade de São Paulo, WHO Collaborating Centre for Nursing Research Development, Ribeirão Preto, SP, Brazil.

${ }^{4}$ PhD, Professor, Escola de Enfermagem de Ribeirão Preto, Universidade de São Paulo, WHO Collaborating Centre for Nursing Research Development, Ribeirão Preto, SP, Brazil.

${ }_{5}$ PhD, Professor, Universidade de Ribeirão Preto, Ribeirão Preto, SP, Brazil.
}

Corresponding Author:

Diene Monique Carlos

Universidade de São Paulo. Escola de Enfermagem de Ribeirão Preto

Av. dos Bandeirantes, 3900

Bairro: Monte Alegre

CEP: 14040-902, Ribeirão Preto, SP, Brasil

E-mail: diene_enf@yahoo.com.br 


\section{Introduction}

Violence is diffused throughout the social fabric, configuring itself as a serious public health problem. Children and adolescents, at the specific period of growth and development in which they find themselves, become the main victims of this problem, and the highest rates of violence against this population occur within households ${ }^{(1)}$.

Domestic violence against children and adolescents occurs in intergenerational and hierarchical relationships. These individuals relate to them by means of aggressive acts for resolving conflicts, and as an educational strategy; it also includes the lack of basic care for their children. Because it occurs in the private sphere, it can be extended for a long period, and its identification can be made difficult(2).

Public policies for the protection of children and adolescents evolved in recent decades, within the Brazilian Federal Constitution of 1988 and later by the enactment of the Statute of the Child and Adolescent (ECA), mainly in terms of recognizing children and adolescents as subjects with rights. An important aspect of the ECA is the change of conceptions concerning public intervention with children and adolescents; prior to their implementation, the institutionalization of children and adolescent victims of violence was one of the main pillars of the policies geared to this population(3).

The ECA moved forward to advocate the deinstitutionalization, privileging the guidance of the family, school integration, the family / community articulation, and placement in a foster family, with institutional care to be used in exceptional conditions. Also according to the ECA, this institutionalization is an interim measure, to be used as a way to transition to placement in a foster family, and not implying the deprivation of liberty ${ }^{(3)}$.

Thus, the host institution must evolve from a singular service, to be understood as a place that provides care under the physical conditions of wholesomeness, safety and adequate education, which guarantees the respect and care required for children and adolescents, and that is not a place of segregation ${ }^{(4-5)}$.

It is understood that the family is configured as the primary protective factor for its children; when it appears silent, as shown in this article, it is an exceptional measure when it becomes necessary to remove the child or adolescent; in this way, the host institution presents itself as a space for this attention. However, it is assumed that this context does not effectively takes on the role of protection of childhood and adolescence.

Under this presumption, the protective factors in the institutional context to which adolescent victims of domestic violence are submitted and / or to which they have access, present themselves as an object of study. The protective factors are characteristics that diminish the probability of a negative outcome occuring in the presence of a stressor, reducing its incidence and severity ${ }^{(6)}$.

Nursing has made violence against children and adolescents an object of study in nursing research, given the current magnitude of this phenomenon in society. Such research addresses the characterization of violence and interventions initiated with the childjuvenile population ${ }^{(7-8)}$. However, it is considered essential to "give voice" to the actors involved in the violence, because this look can contribute to the implementation of effective action when facing this phenomenon. It also considers that the the protective factors approach enables a paradigm shift in the care for the child and the adolescent, with a health promotion focus.

Given the above, the objective of this study was to understand and analyze, from the perspective of adolescent victims of domestic violence who were cared for institutionally, the protective factors to which they are submitted and / or have access.

\section{Methodology}

For the design of the current research we adopted a qualitative approach, considered as one "that applies to the study of history, relationships, representations, beliefs, perceptions and opinions, products of the interpretations that humans make with respect to how they live, construct their artifacts and for themselves, feel and think"(9). This study was designed as strategic social research, which is based "on the social science theories, but oriented towards concrete problems, foci, that arise in society, that arise in society, even if it is not up to the investigator, the practical solutions to the indicated problems"(9).

The work was developed in a Non-Governmental Organization (NGO), co-financed by the Prefecture of the Municipality of Campinas; it presents itself as a service for institutional care of children and adolescents referred by the Guardian Council or Court of Childhood and Youth, inserted into the Secretary of Citizenship, Assistance and Social Inclusion, in the area of Special Social Protection of High Complexity. In 2009, 176 children and adolescents presented there. 
The convenience sample was composed from the following principles of inclusion: (i) consider as adolescents those 12 to 18 years, as the age range considered by ECA, who were victims of domestic violence and were receiving institutional care, (ii) consider only the adolescents who were allowed to participate in the survey by the legal guardian of the institution and who accepted to participate by signing the terms of free and informed consent form (TFIC). The sample was defined by the criterion of saturation in the field, based on the recurrence of information ${ }^{(9)}$. The service of the host institution presented a report with 66 adolescents who were included in these principles; of these, 17 adolescents were selected, due to greater availability of schedules between mornings and afternoons for participating in the focus groups, seeking equity between female and male genders.

Data collection was conducted through focus groups and semi-structured interviews. Focus groups are used to focus the research within the goal, to better define the issues, to implement the information about the knowledge of the group in question, and to develop hypotheses for further studies. The semistructured interviews depart from certain questions, generally guided by an outline, that orient a conversation with a definite purpose, not presenting any obstacle and having no means to foresee all conditions or situations of the fieldwork ${ }^{(9)}$.

The insertion of the researcher into the field of study occurred in February of 2009, prior to data collection, by means of a proposal of training for professionals of the host institution, individual nursing care, and leading informative groups with topics brought by adolescents, with weekly frequency.

Upon completion of this initial project, in September of 2009, data collection began, with the completion of two focus groups. The groups took place at the host site, in a video room, lasting approximately 50 minutes. We used the following guiding questions: What is protection for you? What people or places are considered to be protection for you? The groups were recorded with a MP-4 player and some observations were noted by the researcher. All of the adolescents showed themselves to be receptive and adherent to the invitation to participate in the study, after clarification of the TFIC and obtaining their signature.

At the end of the groups, we provided the invitation to teens to participate in individual interviews, and all were willing to participate. Seven individual interviews were conducted at times preestablished together with the coordinator of the institution, so it did not interfere with the daily activities of the adolescents. The script established two orienting questions: How do you feel being here at the shelter? Are there services or people that will protect or help you in your daily life? If yes, who/what are they? After the seventh interview, data gathering was discontinued, since it was believed that data saturation had been reached(9).

The study was reviewed by the Committee on Ethics in Research of the School of Nursing of Ribeirão Preto, University of São Paulo (Universidade de São Paulo - EERP / USP), in compliance with Resolution 196/96 proposed by the National Health Council (CNS) of the Ministry of Health, and was considered approved under Protocol No. 1080/2009. After this approval, authorization was requested to coordinate the residential care service in question to collect data on adolescents, and the legal guardian for the participants also signed the TFIC. To ensure the secrecy of information, the letters "GF" were used to represent the speech of focus groups, and the numbers I and II to represent the first and second focus group conducted, respectively. For the interviews, the names used by adolescents were fictitious, being chosen by them during their interviews.

Data were analyzed using the method of thematic content analysis(10). For operationalization of this method, the following steps were executed: preanalysis; exploration of the material, and treatment of the results. We performed a comprehensive analysis of the documents (reports from focus groups and interviews); pulling out the central ideas from these documents, and from these ideas, we organized the thematic units presented in the following section.

\section{Results and Discussion}

At the end of the analysis process, the following themes emerged: Four walls and Trust.

\section{Four walls}

In this study, the rules and disciplinary strategies present in the context of institutional care were seen by the adolescent participants, as a reflection about the real effectiveness and adequacy of these strategies: Because, when you are ready or do something wrong, they send a report to the "father" [the responsible person at the social institution of care]. Then the "father" gives a disciplinary measure for you, you know, or weed the garden, or wash the bathroom, or clean the whole house, or raking, these things, you know; that to me, I think it is a waste of time, which is something like always 
rubbing it in my face, blackmailing me! (...) Because I come, take the report, pay my discipline and its over, there is no point to it at all. (Negro)

The literature indicates that, apart from institutional care being part of the public policies for social protection of various societies, it still presents itself, despite all the efforts made contemporaneously, as an entity that reproduces the characteristics of total institutions (prisons, orphanages, asylums, convents)(11-12). This problem exposes children and adolescents to various risk situations, such as social segregation and disruption of family ties. Thus, beyond the shelter serving as temporary housing for this population, offering leisure practices, activities designed as formative, educational, correctional or therapeutic, it can present other characteristics. These include the existence of a group of numerous people in the same space, being subjected to the authority exercised by a team leader who entirely manages the dynamics of institutional life, disregarding the unique characteristics of each social actor(13-14).

Disciplinary practices, fulfilled through coercive control as punishment and withdrawal of pleasurable activities, also reinforce an environment surrounded by authoritarianism(12). The issue of lack of freedom, directly associated with this "exaggeration" of standards and the condition of being cared for institutionally, was evidenced by adolescents as a negative aspect for the exercise of their identities as persons: Ah! I will not say that occasionally I would, you know, as I commented in the group, especially when I'm leaving home, four thirty $\mathrm{pm}$, in the bus full of girl, so tight, that stench of sweat, then you look out there, the late afternoon, you know, we feel like we're out there. (Céu).

In this sense, it was perceived that the host institution acts as an important facilitator or complicator for the elaboration of life experiences of these individuals in their phase of adolescence. We highlight the importance of individualizing these issues to the actors of our study, and to cause a reflection of the adolescent in the context of care, for those who experience the process of "adolescence" in distinct conditions. A major aspect to be considered is the lack of familiar figures, which immediately assume parental roles ${ }^{(15)}$.

It is understood to be important to discuss the host institution as the developmental context for children and adolescents. This approach has been emphasized in the last decade, and presents itself as an important tool for studies and research that are concerned with expanding the vision about children and adolescents who find themselves in a vulnerable situation. To this end, the ecological approach is used for human development ${ }^{(16)}$, that the context in which the person grows and develops is not limited to one immediate and unique environment, but it establishes the existing connections between the environments to which the individual has access, and with the primary focus on established intraand inter-environmental relationships. According to this approach, the environments to which the individual has access are analyzed in four types of systems, among which are included: the microsystem, mesosystem, exosystem, and macrosystem. There are several studies addressing the ecological model of development of children and adolescents in the family, but new research has recently been implemented making other institutions as welcoming to human development. It is pointed out that there is still little information about the activities and relationships that characterize institutional environments, and the similarities to or differentiation from the family context ${ }^{(16-17)}$.

The literature brings protective factors and risks encountered in host institutions, that directly or indirectly influence the development of the actors who live in these locations. According to some authors, some families possess a physical and social environment so poor and chaotic, that the insertion of the child or adolescent in an institution already contributes to a better promotion of physical and mental health of these actors; some adolescents encounter important resources for coping with adversities when included in this context. Other authors cite that the supply of basic human needs alone (food, peaceful sleep, appropriate clothing) already constitutes a positive event for children and adolescents cared for institutionally ${ }^{(16-17)}$.

The host institution within the context of protection appears in the speech of the adolescents. The limits and rules are perceived as self-restraining determinants that they need; such restraint seems to be found in environments with some stability and reciprocity ${ }^{(15)}$. The report of "to be protected is to be between the four walls" (GF II) refers to this meaning. It is understood that the protection factor is the institutional environment, and not the determination of norms: I do not know ... ah, I think if I had a lot of freedom, it would be bad, people have gone wrong...Removing the rules (...) Outside I had school, class, more freedom, and did not enjoy it ... suddenly the place is right, is not it? (Pincel)

Family cohesion, that is, the affective proximity, involving relationships of friendship and unity among members, and promoting the healthy development and psychosocial well-being of the child, adolescent and 
their families, presents itself as an important protective factor for these actors ${ }^{(18)}$. Ecological cohesion is a term equivalent to family cohesion, but is used when the child or adolescent lives in other contexts, they are also considered places where the individual develops, such as institutions and the street ${ }^{(17,19)}$. Although children and adolescents cared for institutionally are considered to be in at risk situations a priori, this fact "has not been reflected in reality"(17). The ecological cohesion is characterized by the absence of negligence, as an environment that promotes coping with conflicts, by the presence of at least one adult with an interest in the child or adolescent, generating affective ties that provide support in times of stress and adversities ${ }^{(18)}$.

For this cohesion to happen, the existence of interactions is of paramount importance, independent of the microsystems in which people are or where they live. These interactions need to be permeated by positive feelings of affection, reciprocity and balance of power ${ }^{(16)}$. The literature demonstrates that both abusive or neglectful relationships, as with relationships permeated with affection and reciprocity, can be encountered in educational practices in the family, institution or school; when there exist "positive connections between and / or within contexts, there will be possibilities that (...) promote improved quality of life and adaptation / health of people and society"(17).

It is revealed that the above discussion comes up against the transitory character recommended by ECA for the permanence of children and adolescents in host institutions. Despite new laws and looks forward to this question for this issue, children and adolescents still remain for long periods in these institutions, due to the impossibility of returning to the family of origin or for insertion in a foster family. Many times, the institution welcomes children and adolescents as if they were in transit, weakening or invalidating this ecological cohesion that would signify a protection factor for these $\operatorname{actors}^{(15)}$.

\section{Trust}

The adolescents emphasized the interactions and humanized relationships that they established with some professionals in the institution studied, and they considered them as one of the major protective factors present in this context. It is evident that, due to previous experiences in the family (lack of affection, dialogue, care), the adolescents encountered the employees who worked in this institution as the means for supplying these needs. This relationship, permeated by affection and reciprocity, is valued by adolescents; they believe that it is intimately related to the sense of safety and connection they experience in their daily lives. The "trust" is evidenced in reports: Because I think that for it to come, to trust, I must talk, it is not my way but I have to conquer myself, I understand (...) When I was doing something wrong, they would sit and talk, rather than already saying I was wrong ... Then I looked, they did not speak in front of others ... I think they came with more love, they came and gave more affection ... (Jaci).

Employees of sectors to support the adolescents, such as administration and laundry, and the foster parents are referred to as protective factors. It is noticed that these people have in common the ability to listen to others, to show differentiated and qualified listening, and to position themselves empathically. According to the literature, environments that welcome children and adolescents should have a new look in front of these actors, providing spaces with greater trust and empathy, and creating environmental conditions to develop their potentials with greater social and subjective support. According to these authors, a new listener, or a differentiated listener, could reframe the history of the adolescent, allowing greater capacity for reflection and less action; in this sense, the selection of people to play the caring role for children and adolescents in the context of care is of paramount importance $^{(6,15)}$. Attentive is needed to the fact that, given the physical and emotional burden that the care for these adolescents brings, it is necessary to build a network of support for these caregivers. In a study that aimed to identify strategies discussed and utilized by professional caregivers in shelters, in situations of violence experienced by adolescents, they reported that they often faced a "lonely fight", because they felt that the family demonstrated the omission of the protective role for the children and adolescents, but they understood that both these actors and their families needed to be inserted into intersectoral support networks ${ }^{(20)}$.

Religiosity was cited by adolescents as a protective factor. This theme, in particular the Protestant practice, was very present in the institution, and meetings existed for this purpose three times a week, with the coordination of the service performed by a pastor. The teenagers indicated that this was a positive factor in everyday life, showing the figure of God as, many times, the only mechanism that effectively accomplished this protection: Oh, beyond the structure they give to us, the teaching, they prepare us for the job market, but I think the most important part is God ...(Pincel). 
It is understood that it is important in this context to discuss the differences between the concepts of religiosity and spirituality, in order to justify the use of the term religiosity in this work. According to the literature, spirituality is an individual characteristic, that may or may not include a belief in a god, and is configured in a personal quest for answers about the meaning of life, the universe and relationships with others(21-22). Religiosity represents an organized system of beliefs and practices proposed by a religion for the individual approach of the sacred and / or transcendent (God, Higher Power, Ultimate Reality), being connected, therefore, to a specific doctrine shared with a group. Thus, it is understood that the concept of religiosity includes individual and institutional aspects, while spirituality is an individual phenomenon, identified with aspects of personal transcendence and a source of meaning for life events(23). We decided to use the concept inherent in religion / religiosity in this study, because we believed that it adapted best to the results we encountered (orientation of a particular doctrine; belief in God).

Religiosity is cited as a protective factor for several disease states. Spirituality and belief in a higher being appeared as protective factors related to the use of psychoactive substances for undergraduate students(24). A recent study demonstrated that both religious affiliation and religious practice discriminated against and diminished the exposure to health risk behaviors in adolescents $^{(25)}$.

In addition to the relationships with the employees of the religious institution, the adolescents brought some friends as protective factors and with whom they shared this feeling of trust. The social coexistence in a common space, every day, was raised by the actors of the study as beneficial, although difficult: (...)So it gives a good structure for us, especially when we go out there because, just living in a house with 16 different girls, eh, you know that everywhere in your life you will find people you get along with well or not so well, there will be the person you do not like but you will have to learn to live with ... (Céu)

The data encountered reinforced the group tendency present in adolescence, which provides the actors, through the process of identification, security and personal esteem the necessities for the transition to the adult world and a healthy development(5).

\section{Final Conclusion}

In this study, it was noticed that the service of the host institution still maintains characteristics of total institutions and asylums, with some postures and authoritarian practices, such as the considerable number of rules and punishments. Despite the fact that the institution is legally considered to be a transitional home, for children and adolescents deprived of the family environment, in the majority of cases it becomes a permanent home, especially for adolescents. In addition to the various issues that must be considered in order to avoid this prolonged stay, due to the present legal provision that deals with institutional reorganization and the mode of action of host programs and their integration into the municipal policy of social assistance, the discussion of institutional care within the context of human development is understood to be necessary. This theme becomes important to the aim of minimally offering an environment attentive to their individuality, and that is configured as a protection for the adolescents welcomed there. In this sense, it is essential to conduct interactions, and the adolescents highlighted as protective factors: trust, and the bonds established with service professionals, religiosity and with their friends.

This current analysis of protective factors that adolescent victims of domestic violence who are subject to institutional care and / or to which they have access, presented limitations, because its results cannot be generalized for presenting special features of the actors studied. However, despite these specific characteristics, the research provides insights that contribute to technical-scientific nursing, indicating way to (re)define the care for children and adolescents in situations of personal and / or social risk, and to promote physical and mental health of these actors

Further studies addressing protective factors in other contexts for children, adolescents and families that experience domestic violence; interagency and intersectoral practices to face this violence against children and adolescents; and, the dynamic of the host institutionss functioning toward the child-adolescent population are recommended.

\section{References}

1. Ministério da Saúde (BR). Impacto da violência na saúde das crianças e adolescentes. Brasília (DF): Editora do Ministério da Saúde; 2009. 15 p.

2. Ministério da Saúde (BR). Secretaria de Atenção a Saúde. Departamento de Ações Programáticas e Estratégicas. Linha de cuidado para a atenção integral à saúde de crianças adolescentes e suas famílias em 
situação de violências: orientação para gestores e profissionais de saúde. Brasília (DF): Ministério da Saúde; 2010. 104 p.

3. Lei no 8.069, de 13 de julho de 1990 (BR). Atualizado em novembro de 2003, em conformidade com a Lei no 10.764 , de 12 de novembro de 2003, que altera a Lei no 8.069, de 13 de julho de 1990. Brasília (DF): Senado; 1990.

4. Silva ERA, organizador O direito à convivência familiar e comunitária: os abrigos para crianças e adolescentes do Brasil. Brasília (DF): IPEA; 2004. 11 p.

5. Gontijo DT, Medeiros M. Crianças e adolescentes em situação de rua: contribuições para a compreensão dos processos de vulnerabilidade e desfiliação social. Ciênc Saúde Coletiva. 2009;14(2):467-75. doi: 10.1590/ S1413-81232009000200015.

6. Costa COM, Bigras M. Mecanismos pessoais e coletivos de proteção e promoção da qualidade de vida para a infância e adolescência. Ciênc Saúde Coletiva. 2007;12(5):1101-9. doi: 10.1590/S141381232007000500002 .

7. Apostolico MR, Nóbrega CR, Guedes RN, Fonseca RMGS, Egry EY. Characteristics of violence against children in a Brazilian Capital. Rev. Latino-Am. Enfermagem. 2012;20(2):266-73. doi: 10.1590/S010411692012000200008. Inglês, Português, Espanhol.

8. Silva LMP, Ferriani MGC, Silva MAI. Judiciary as the last resort to protect children and adolescents: intersectoral actions, investment in human resources, and structuring of services. Rev. Latino-Am. Enfermagem. 2012;20(3):444-52. doi: 10.1590/S010411692012000300004. Inglês, Português, Espanhol.

9. Minayo MCS. O desafio do conhecimento: pesquisa qualitativa em saúde. 12 ed. São Paulo (SP): Hucitec; 2010. 407 p.

10. Bardin L. Análise de conteúdo. Lisboa: Edições 70; 1977. 287 p.

11. Goffman E. Manicômios, prisões e conventos. 8 ed. São Paulo (SP): Perspectiva; 2008. 312 p.

12. Prada CG, Weber LND. O abrigo: análise de relatos de crianças vítimas de violência doméstica que vivem em instituições. Rev Psicol UNESP. 2006;5(1):1-12.

13. Benelli SJ. Dispositivos disciplinares produtores de subjetividade na instituição total. Psicol Estudo. 2003;2(1):99-114.

14. Cavalcante LIC, Magalhães CMC, Pontes FA. Abrigo para crianças de 0 a 6 anos: um olhar sobre as diferentes concepções e suas interfaces. Rev Mal-Estar Subj. 2007;7(2):329-52.
15. Oliveira APG, Milnitsky-Sapiro C. Políticas públicas para adolescentes em vulnerabilidade social: abrigo e provisoriedade. Psicol Cienc Prof. 2007;27(4):623-35. 16. Bronfenbrenner U. Making human beings human: bioecological perspectives on human development. Thousand Oaks, CA: Sage; 2004.

17. Poletto $\mathrm{M}$, Koller $\mathrm{SH}$. Contextos ecológicos: promotores de resiliência, fatores de risco e de proteção. Estud Psicol. 2008;25(3):405-16.

18. De Antoni C, Teodoro M, Koller SH. Coesão e Hierarquia em Famílias com História de Abuso Físico. Univ Psy. 2009;8:399-412.

19. Morais NA, Koller SH. Abordagem ecológica do desenvolvimento humano, psicologia positiva e resiliência: a ênfase na saúde. In: Koller $\mathrm{SH}$, organizador. Ecologia do desenvolvimento humano: pesquisa e intervenção no Brasil. São Paulo (SP): Casa do Psicólogo; 2004. p. 91-107.

20. Penna LHG, Carinhanha JI, Leite LC. The educative practice of professional caregivers at shelters: coping with violence lived by female adolescents. Rev. LatinoAm. Enfermagem. 2009;17(6):981-7. doi: 10.1590/ S0104-11692009000600009. Inglês, Português, Espanhol.

21. Sanchez ZM, Nappo SA. A religiosidade, a espiritualidade e o consumo de drogas. Rev Psiq Clin. 2007;34(1):73-81.

22. Faria JB, Seidl EMF. Religiosidade e enfrentamento em contextos de saúde e doença: revisão de literatura. Psicol Reflexão Crítica. 2005;18(3):381-9.

23. Miller WR, Thoresen CE. Spirituality, religion and health: an emerging research field. Am Psychol. 2003;58(1):24-35.

24. Morales BN, Plazas M, Sanchez R, Ventura CAA. Risk and protection factors related to the consumption of psychoactive substances in undergraduate nursing students. Rev. Latino-Am. Enfermagem. 2011;19(spe):673-83. doi: 10.1590/S010411692011000700003. Inglês, Português, Espanhol.

25. Bezerra J, Barros MVG, Tenório MCM, Tassitano RM, Barros SSH, Hallal PC. Religiosidade, consumo de bebidas alcoólicas e tabagismo em adolescentes. Rev Panam Salud Publica. 2009;26(5):440-6. doi: 10.1590/ S1020-49892009001100009. 